\title{
ANALISIS KUAT TEKAN BATU BATA DENGAN ONGGOK SEBAGAI BAHAN PENGGANTI SEKAM PADI
}

\author{
Ngudi Hari Crista ${ }^{1}$ Agus Muldiyanto ${ }^{2}$ \\ 1Jurusan Teknik Sipil Universitas Semarang \\ 2Jurusan Teknik Sipil Universitas Semarang
}

\begin{abstract}
The most widely used material as a house wall is red brick, which is relatively cheap and safe to weather compared to other materials. Red bricks are usually in the manufacturing process by traditional means and fabrication. In general red bricks require additional materials of rice husk in the process of making. Much of the "starchy" waste material widely found in Klaten that is not currently utilized, is expected to be used instead of rice husk which is one of the red brick material mixtures. This research will be conducted brick test with mechanical behavior test which includes density test, water absorption test and compressive strength test with red brick made from rice husk mixture as comparison with analysis result of mixture of starch onggok waste. The result of this research is compressive strength of brick with mixture of rice husk larger and has a small water absorption compared with compressive strength of brick with mixture of onggok.
\end{abstract}

Keywords; brick, waste starch onggok, mixed mixture

\begin{abstract}
Abstrak
Bahan material yang paling banyak digunakan sebagai dinding rumah adalah batu bata merah, yang harganya relative murah serta aman terhadap cuaca dibandingkan dengan bahan lainnya. Batu bata merah biasanya dalam proses pembuatan dengan cara tradisional dan pabrikasi. Pada umumnya batu bata merah memerlukan bahan tambahan sekam padi dalam proses pembuatannya. Banyak bahan limbah " pati onggok" yang banyak terdapat di Klaten yang sampai saat ini tidak dimanfaatkan, diharapkan dapat digunakan sebagai pengganti dari sekam padi yang merupakan salah satu material campuran batu bata merah. Penelitian ini akan dilakukan pengujian batu bata dengan uji perilaku mekanis yang meliputi uji densitas,uji daya serap air dan uji kuat tekan dengan batu bata merah yang terbuat dari campuran sekam padi sebagai pembanding dengan hasil analisis campuran limbah pati onggok. Hasil penelitian ini kuat tekan batu bata dengan campuran sekam padi lebih besar dan memiliki daya serap air kecil dibandingkan dengan kuat tekan batu bata dengan campuran onggok.
\end{abstract}

Kata kunci ; batu bata, limbah pati onggok, pengganti campuran

\section{PENDAHULUAN}

Batu bata merah merupakan bahan material di bidang konstruksi bangunan, batu bata merah didefinisikan sebagai suatu komposisi bahan bangunan yang terbuat dari campuran tanah liat dengan sekam padi serta air yang dicampur rata. Selanjutnya dikeringkan dibawah sinar matahari, tahap akhir dengan membakarnya dengan suhu tertentu sampai berwarna kemerah- merahan untuk menghasilkan batu bata yang berkualitas. Batu bata merupakan material bangunan yang berfungsi sebagai peyekat dinding bangunan agar terlindung dari cuaca luar dan sebagai estetika tata letak ruangan.

Kebutuhan rumah atau tempat tinggal sangat meningkat seiring dengan pertambahan jumlah penduduk, untuk itu pemerintah sedang giat membangun perumahan untuk rakyat, tentunya tidak terkecuali peran swasta juga dilibatkan dalam pemenuhan kebutuhan masyarakat akan rumah atau tempat tinggal. 
Bahan material yang paling banyak digunakan sebagai dinding rumah adalah batu bata merah, yang harganya relative murah serta aman terhadap cuaca dibandingkan dengan bahan lainnya. Batu bata merah biasanya dalam proses pembuatan dengan cara tradisional dan pabrikasi. Kualitas batu bata merah dengan cara tradisional hanya mampu menghasilkan jumlah batu bata merah yang terbatas untuk setiap kali produksi. Dibandingkan batu bata buatan pabrik yang memakai mesin dan memerlukan pekerja yang sedikit. Pembuatan batu bata merah cara tradisional membutuhkan tenaga manusia yang lebih banyak. Sehingga dapat membuka lapangan pekerjaan untuk masyarakat sekitar. Pada umumnya batu bata merah memerlukan bahan tambahan sekam padi dalam proses pembuatannya.

Di Indonesia telah banyak bahan-bahan limbah yang telah diuji coba untuk mengurangi ketergantungan material beton seperti tetes tebu, ampas tebu, sekam dan lain-lain. Penggunaan limbah "pati onggok" yang banyak terdapat di Klaten yang sampai saat ini tidak dimanfaatkan, menarik perhatian peneliti untuk mengadakan penelitian untuk mencoba sebagai bahan pengganti sebagian dari material campuran batu bata merah sebagai pengganti sebagian atau seluruhnya bahan sekam. Peneliti memilih batu bata merah karena batu bata banyak digunakan jumlah yang besar untuk rumah tinggal sebagai dinding. Selain itu karena sifat fisik limbah pati onggok yang berbentuk seperti sekam dan sifat kimia seperti suhu nyala api yang tinggi serta tidak berasap, maka limbah pati onggok diharapkan dapat digunakan sebagai pengganti sebagian atau seluruhnya dari sekam padi yang merupakan salah satu material campuran batu bata merah

\section{METODE PENELITIAN}

Metode yang digunakan dimulai dari tahapan pengambilan sampel benda uji batu bata berrongga sebanyak 36 buah dengan jumlah sampel uji masing - masing variasi sebanyak 9 buah, Untuk variasi dapat dilihat pada tabel 1.

Tabel 1 Jumlah Sampel batu bata

\begin{tabular}{|c|l|c|}
\hline No & \multicolumn{1}{|c|}{ Jenis Campuran } & Jumlah \\
\hline 1 & Bata sekam padi & 9 buah \\
\hline 2 & $\begin{array}{l}\text { Bata + Sekam + Onggok } \\
25 \%\end{array}$ & 9 buah \\
\hline 3 & $\begin{array}{l}\text { Bata + Sekam + Onggok } \\
50 \%\end{array}$ & 9 buah \\
\hline 4 & Bata + Onggok 100\% & 9 buah \\
\hline
\end{tabular}

Sumber : Peneliti, 2017

Setelah sampel uji selesai maka uji perilaku mekanis batu bata berrongga dapat dilakukan, antara lain :

1. Uji pengamatan dimensi batu bata berrongga

Sampel yang sudah siap dilakukan pengukuran dimensi meliputi ukuran panjang , lebar ,tebal ,warna , kesikuan, dan permukaan batu bata. Uji ini untuk membandingkan antara hasil sampel benda yang sudah jadi dengan syarat standar ukuran batu bata sesuai SNI 
2. Uji Densitas

Sampel yang sudah jadi dilakukan pengujian density. Dengan cara menimbang sampel posisi kering udara dan menghitung volume masing masing benda uji. Selanjutnya data dapat dihitung dengan rumus :

$$
\text { Density = massa kering / volume }
$$

3. Uji Suction rate ( Daya Serap AII)

Sampel yang sudah jadi pengujian suction rate. Proses pengujian dengan melakukan penimbangan sampel dalam keadaan kering, kemudian dilakukan perendaman permukaan sampel sedalam $1 \mathrm{~cm}$ kedalaman permukaan air, dengan lama waktu perendaman 3 menit. Selanjutnya sampel diangkat dan dilakukan penimbangan setelah penyerapan air. Data dapat dihitung dengan menggunnakan persamaan section rate:

$$
\text { Penyerapan }=\frac{100(\text { ws wd) }}{W d}(\%)
$$

4. Uji Kuat tekan batu bata berrongga

Uji kuat tekan batu bata adalah kemampuan batu bata untuk menahan beban maksimun sebelum batu bata hancur

Kuat tekan suatu material didefinisikan sebagai kemampuan material dalam menahan beban atau gaya mekanis sampai terjadinya kegagalan (failure).

$\mathrm{P}=\mathrm{F} / \mathrm{A}$

Dimana :

$\mathrm{P}=$ Nilai kuat tekan $\left(\mathrm{Kg} / \mathrm{cm}^{2}\right)$

$\mathrm{F}=$ Beban maksimum $(\mathrm{Kg})$.

$A=$ Luas bidang permukaan $\left(\mathrm{cm}^{2}\right)$.

Untuk pengujian dimensi, uji density, section rate dan kuat tekan dilakukan pengolahan data secara analisis meliputi perhitungan rata-rata, serta penggambaran grafik sampel benda uji sesuai dengan uji yang telah dilakukan. Untuk analisa data pada percobaan kuat tekan batu bata berrongga dilakukan uji statistik terhadap benda uji antara lain simpangan baku benda uji,standar deviasi, dari data uji statistik dilakukan pengambaran grafik sederhana untuk menggambarkan kondisi kuat tekan yang dihasilkan masing -masing sampel.

$$
\begin{aligned}
& \text { Rata rata }=\frac{\in \text { jumlah data }}{\mathrm{n}} \\
& \text { Simpangan baku }=\sqrt{\frac{\sum_{n=1}^{n} x-\bar{x}}{n-1}}
\end{aligned}
$$

\section{ANALISIS DAN PEMBAHASAN}

Hasil analisis ini berdasarkan sampel yang diuji dengan perilaku mekanis yang meliputi pengamatan dimensi, uji densitas benda uji, dan uji kuat tekan batu bata berongga yang akan dihasilkan data dan laporan dari uji tersebut.

1. Uji pengamatan batu bata berongga

Berdasarkan hasil pengamatan dan dilakukan pengukuran batu bata normal dari 9 sampel didapat panjang rata - rata $21,58 \mathrm{~cm}$, lebar rata - rata $9,08 \mathrm{~cm}$ dan 
tebal rata - rata 4,70 $\mathrm{cm}$ dengan warna merah tua dengan ketajaman, kesikuan serta keadaan permukaan rata rata baik. Hasil tabulasi ini disajikan sebagai berikut.

Tabel 1 : Hasil Pengukuran Batu Bata Normal

\begin{tabular}{|c|c|c|c|c|c|c|c|c|}
\hline \multirow{10}{*}{ 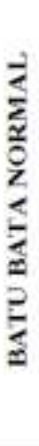 } & BENDA UI & PANUANG (CM) & LEBAR (CM) & TEBAL (CM) & WAKNA & KESIKUAS & KETAJAMAXSUDTT & KEADAAX PERMIKAAS \\
\hline & 1 & 21,70 & 9,00 & 4,00 & Merki ta & Baik & Baik & Rata den Tidak Retak \\
\hline & 2 & 21,70 & 8,80 & 5,30 & Mersh tua & Kurnes: & Kurang & Rata dan Tidak Retsk \\
\hline & 3 & 22,20 & 9,60 & 4,40 & Menh Tra & Beik & Baik & Tidak Rata dan Retes \\
\hline & 4 & 21,50 & 8,60 & 4,80 & Merak Ta & Baik & Baik: & Rata dan Tidak Retak \\
\hline & 6 & 21,70 & 9,30 & 5,00 & Merab Tea & Bail. & Baik & Rata dan Tidak Retak \\
\hline & 7 & 21,20 & 9,20 & 5,10 & Mernk Twa & Baik & Baik & Rata dan Tidak Retak \\
\hline & 8 & 21,30 & 9,10 & 4,80 & Mernh Tra & Baik & Baik & Rata dan Tidak Retak \\
\hline & 9 & 21,70 & 9,10 & 4,30 & Mernat Tea & Baik & Kurang & Tidak Rata dam Retak \\
\hline & RATARAIA & 21,58 & 9,08 & 4,70 & & & & \\
\hline
\end{tabular}

Sumber : Hasil Analisis Peneliti, 2017

Di tinjau pengukuran batu bata berongga dengan campuran onggok $25 \%$ terlihat panjang rata - rata $21,2 \mathrm{~cm}$, lebar $9,20 \mathrm{~cm}$ dan tebal 4,70 dengan warna coklat muda, serta kondisi kesikuan,ketajaman sudut dan keadaan permukaan tidak rata.

Tabel 2 Hasil Pengukuran Batu Bata dengan Onggok 25\%

\begin{tabular}{|c|c|c|c|c|c|c|c|c|}
\hline \multirow{10}{*}{ 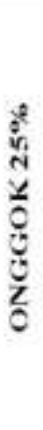 } & 1 & 2100 & 9,20 & 4,50 & Coklat Muda & Baik & Baik & Tidak Rata don Recak \\
\hline & 2 & 21,50 & 9,20 & 4,50 & Coklat Moda & Beik & Baik & Tidat Rata don Retak. \\
\hline & 3 & 21,50 & 9,50 & 4,80 & Coklat Moda & Buik & Baik & Tidai Rata dan Retak \\
\hline & 4 & 21,00 & 9,50 & 4,70 & Cokiar Mods & Baik & Baik & Tidak Rata dn Retak \\
\hline & 5 & 21,00 & 9,50 & 4,50 & Coklat Muda & Baik & Baik & Tidak Rata dan Retak \\
\hline & 6 & 21,00 & 9,00 & 5,00 & Collat Muda & Baik & Baik & Tidak Rata dan Retak \\
\hline & 7 & 22,00 & 9,00 & 4,80 & Coklat Moda & Baik & Kurang & Tidak Rata dinn Retak \\
\hline & 8 & 21,00 & 8,90 & 4,50 & Coklan Moda & Baik & Baik & Tidak Rata din Reak \\
\hline & 9 & 21,00 & 9,00 & 5,00 & Coklat Muda & Baik & Baik & Tidai Rata dar Retak \\
\hline & RATA-RATA & 21,22 & 9,20 & 4,70 & & & & \\
\hline
\end{tabular}

Sumber : Hasil Analisis Peneliti, 2017

Untuk batu bata berongga dengan campuran onggok $50 \%$ terlihat panjang rata rata $22,42 \mathrm{~cm}$, lebar $9,41 \mathrm{~cm}$ dan tebal 4,81 dengan warna coklat muda, serta kondisi kesikuan,ketajaman sudut dan keadaan permukaan tidak rata.

Tabel 3 Hasil Pengukuran Batu Bata dengan Onggok 50\%

\begin{tabular}{|c|c|c|c|c|c|c|c|c|}
\hline \multirow{11}{*}{ 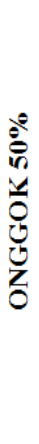 } & BENDA UJ & PANJANG (CM) & LEBAR (CM) & TEBAL (CM) & WARNA & KESIKUAN & KETAJAMAN SUDUT & KEADAAN PERMUKAAN \\
\hline & 1 & 22,50 & 9,20 & 4,50 & Coklat Muda & Kurang & Kurang & Tidak Rata dan Retak \\
\hline & 2 & 22,00 & 9,80 & 4,30 & Coklat Muda & Baik & Kurang & Tidak Rata dan Retak \\
\hline & 3 & 22,00 & 9,50 & 4,50 & Coklat Muda & Baik & Baik & Tidak Rata dan Retak \\
\hline & 4 & 22,00 & 9,20 & 5,00 & Coklat Muda & Baik & Baik & Tidak Rata dan Retak \\
\hline & 5 & 22,30 & 9,80 & 4,00 & Coklat Muda & Baik & Baik & Tidak Rata dan Retak \\
\hline & 6 & 22,50 & 9,50 & 5,50 & Coklat Muda & Baik & Kurang & Tidak Rata dan Retak \\
\hline & 7 & 23,00 & 9,00 & 5,00 & Coklat Muda & Baik & Baik & Tidak Rata dan Retak \\
\hline & 8 & 23,00 & 9,20 & 5,00 & Coklat Muda & Baik & Baik & Tidak Rata dan Retak \\
\hline & 9 & 22,50 & 9,50 & 5,50 & Coklat Muda & Baik & Kurang & Tidak Rata dan Retak \\
\hline & RATA-RATA & 22,42 & 9,41 & 4,81 & & & & \\
\hline
\end{tabular}

Sumber : Hasil Analisis Peneliti, 2017 
Untuk 9 sampel batu bata berongga dengan campuran onggok $100 \%$ terlihat panjang rata - rata $22,72 \mathrm{~cm}$, lebar $9,50 \mathrm{~cm}$ dan tebal 4,72 dengan warna coklat muda, serta kondisi kesikuan,ketajaman sudut dan keadaan permukaan tidak rata.

Tabel 4 Hasil Pengukuran Batu Bata dengan Onggok 50\%

\begin{tabular}{|c|c|c|c|c|c|c|c|c|}
\hline \multirow{10}{*}{ 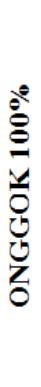 } & 1 & 23,00 & 9,50 & 4,50 & Coklat Muca & Kurang & Kurang & Tidak Rata dan Retak \\
\hline & 2 & 23,00 & 9,20 & 5,00 & Coklat Muca & Baik & Baik & Tidak Rata dan Retal \\
\hline & 3 & 22,50 & 9,50 & 4,50 & Cuklat Muca & Baik & Baik & Tidak Rala damı Relak \\
\hline & 4 & 22,50 & 9,50 & 4,50 & Coklat Muca & Baik & Baik & Tidak Rata dan Retak \\
\hline & 5 & 22,50 & 9,00 & 5,00 & Coklat Muca & Baik & Baik & Tidak Rata dan Retak \\
\hline & 6 & 22,50 & 9,50 & 5,00 & Coklat Muca & Baik & Baik & Tidak Rata dan Retak \\
\hline & 7 & 22,50 & 10,00 & 4,50 & Coklat Muca & Baik & Baik & Tidak Rata dan Retal \\
\hline & 8 & 23,00 & 9,50 & 1,50 & Coklat Muca & Kurang & Kurang & Tidak Rata dan Retal \\
\hline & 9 & 23,00 & 9,80 & 5,00 & Coklat Muca & Baik & Baik & Tidak Rata dan Retak \\
\hline & RATA-RATA & 22,72 & 9,50 & 4,72 & & & & \\
\hline
\end{tabular}

Sumber : Hasil Analisis Peneliti, 2017

2. Uji Densitas

Pada variasi 9 sampel batu bata normal volume yang terjadi rata - rata 919,94 $\mathrm{cm} 3$, beban kering terjadi rata - rata 1092.93 gram, sehingga didapat nilai rata rata densiti $1,19 \mathrm{gram} / \mathrm{cm}^{3}$ penyajian tabulasi dapat dilihat sebagai berikut.

Tabel 5 Hasil Pengujian density Batu Bata Normal

\begin{tabular}{|c|c|c|c|c|c|c|c|}
\hline \multirow{11}{*}{ 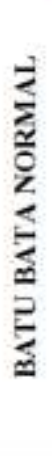 } & BENDACI & PANJANG (CAI) & LEBAR (CM) & TEBAL. (CM) & VOLEMIE. (CAL3) & BEBAN KERING (GRAM) & DENSITY (CRAMUCMS) \\
\hline & 1 & 21,70 & 9,00 & 4,00 & 781,20 & 1177,10 & 1,51 \\
\hline & 2 & 21,70 & 8,80 & 5,30 & 1012,09 & 1047,30 & 1,03 \\
\hline & 3 & 22,20 & 9,60 & 4,40 & 937,73 & 1094,70 & 1,17 \\
\hline & 4 & 21,50 & 8,60 & 4,80 & 887,52 & 1091,10 & 1,23 \\
\hline & 5 & 21,20 & 9,00 & 4,60 & 877,68 & 1002,50 & 1,14 \\
\hline & 6 & 21,70 & 9,30 & 3,00 & 1009,05 & 1205,60 & 1,19 \\
\hline & 7 & 21,20 & 9,20 & 5,10 & 994,70 & 1241,60 & 1,25 \\
\hline & 8 & 21,30 & 9,10 & 4,80 & 930,38 & 1191,00 & 1,28 \\
\hline & 9 & 21,70 & 9,10 & 4,30 & 849,12 & 785,50 & 0,93 \\
\hline & RATA-RATA & 21,58 & 9,08 & 4,70 & 919,94 & 1092,93 & 1,19 \\
\hline
\end{tabular}

Sumber : Hasil Analisis Peneliti, 2017

Pada variasi sampel batu bata dengan onggok $25 \%$ volume yang terjadi rata rata $917.42 \mathrm{~cm} 3$, beban kering terjadi rata - rata 1196.57 gram, sehingga didapat nilai rata - rata densiti $1.31 \mathrm{gram} / \mathrm{cm}^{3}$ penyajian tabulasi dapat dilihat seperti pada tabel dibawah.

Tabel .6 Hasil Pengujian density Batu Bata dengan Onggok 25\%

\begin{tabular}{|c|c|c|c|c|c|c|c|}
\hline \multirow{10}{*}{ 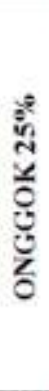 } & 1 & 21,00 & 9,20 & 4,50 & 869,40 & 1228,10 & 1,41 \\
\hline & 2 & 21,50 & 9,20 & 4,30 & 890,10 & 1176,80 & 1,32 \\
\hline & 3 & 21,50 & 9,50 & 4,80 & 980,40 & 1214,50 & 1,24 \\
\hline & 4 & 21,00 & 9,50 & 4,70 & 937,65 & 1185,30 & 1,26 \\
\hline & 3 & 21,00 & 9,50 & 4,50 & 897,75 & 1176,80 & 1,31 \\
\hline & 6 & 21,00 & 9,00 & 5,00 & 945,00 & 1221,90 & 1,29 \\
\hline & 7 & 22,00 & 9,00 & 4,80 & 950,40 & 1198,40 & 1,26 \\
\hline & 8 & 21,00 & 8,90 & 4,50 & 841,05 & 1173,70 & 1,40 \\
\hline & 9 & 21,00 & 9,00 & 5,00 & 945,00 & 1193,60 & 1,26 \\
\hline & RATA-RATA & 21,22 & 9,20 & 4,70 & 917,42 & 1196,57 & 1,31 \\
\hline
\end{tabular}

Sumber : Hasil Analisis Peneliti, 2017

Pada variasi sampel batu bata dengan onggok $50 \%$ volume yang terjadi rata rata $1014.39 \mathrm{~cm} 3$, beban kering terjadi rata - rata 1140.39 gram, dengan demikian didapat nilai rata - rata densiti $1.13 \mathrm{gram} / \mathrm{cm}^{3}$ penyajian tabulasi dapat dilihat seperti pada tabel 7 . 
Tabel 7 Hasil Pengujian density Batu Bata dengan Onggok 50\%

\begin{tabular}{|c|c|c|c|c|c|c|c|}
\hline \multirow{10}{*}{$\begin{array}{l}0^{2} \\
\bar{y} \\
\frac{1}{0} \\
0 \\
0 \\
0 \\
0\end{array}$} & BENDA UJ & PANJAVG (CMI) & LEBAR (CM) & TEBAL (CM) & VOLUMIE (CMI3) & BEBAN KERIVG (CRAM) & DENSITY (GRAMECMB) \\
\hline & 1 & 22,50 & 9,20 & 4,50 & 931,50 & 1099,40 & 1,18 \\
\hline & 2 & 22,00 & 9,80 & 4,30 & 927,08 & 1112,00 & 1,20 \\
\hline & 3 & 22,00 & 9,50 & 4,50 & 940,50 & 1143,10 & 1,22 \\
\hline & 4 & 22,00 & 9,20 & 5,00 & 1012,00 & 1140,80 & 1,13 \\
\hline & 6 & 22,50 & 9,50 & 5,50 & 1175,63 & 1181,60 & 1,01 \\
\hline & 7 & 23,00 & 9,00 & 5,00 & 1035,00 & 1126,90 & 1,09 \\
\hline & 8 & 23,00 & 9,20 & 5,00 & 1058,00 & 1200,20 & 1,13 \\
\hline & 9 & 22,50 & 9,50 & 5,50 & 1175,63 & 1166,60 & 0,99 \\
\hline & RATA-RATA & 22,42 & 9,41 & 4,81 & 1014,39 & 1140,39 & 1,13 \\
\hline
\end{tabular}

Sumber : Hasil Analisis Peneliti, 2017

Pada variasi sampel batu bata dengan onggok $100 \%$ volume yang terjadi rata rata $1018.78 \mathrm{~cm} 3$, beban kering terjadi rata - rata 1109,56 gram, dengan demikian didapat nilai rata - rata densiti $1.09 \mathrm{gram} / \mathrm{cm}^{3}$ penyajian tabulasi dapat dilihat seperti pada tabel dibawah.

Tabel 8 Hasil Pengujian density Batu Bata dengan Onggok 100\%

\begin{tabular}{|c|c|c|c|c|c|c|c|}
\hline \multirow{10}{*}{ 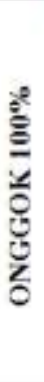 } & 1 & 23,00 & 9,50 & 4,50 & 983,25 & 1115,60 & 1,13 \\
\hline & 2 & 23,00 & 9.20 & 5,00 & 1058,00 & 1149,00 & $1, \infty$ \\
\hline & 3 & 22,50 & 9,50 & 4,50 & 961,88 & 1085,00 & 1,13 \\
\hline & 4 & 22,50 & 9,50 & 4,50 & 961,88 & 1095,30 & 1,14 \\
\hline & 5 & 22,50 & 9,00 & 5,00 & 1012,50 & 1155,70 & 1,14 \\
\hline & 6 & 22,50 & 9,50 & 5,00 & 1068,75 & 1090,10 & 1,02 \\
\hline & 7 & 22,50 & 10,00 & 4,50 & 1012,50 & 1130,00 & 1,12 \\
\hline & 8 & 23,00 & 9,50 & 4,50 & 983.25 & 1096,50 & 1,12 \\
\hline & 9 & 23,00 & 9,80 & 5,00 & 1127,00 & 1068,80 & 0,95 \\
\hline & RATA-RATA & 22,72 & 9,50 & 4,72 & 1018,78 & 1109,56 & 1,09 \\
\hline
\end{tabular}

Sumber : Hasil Analisis Peneliti, 2017

3. Uji daya serap air (Section rate)

Hasil penimbangan batu bata normal pada saat beban basah mempunyai nilai ratarata 1288.71 gram, sedangkan beban kering yang terjadi adalah 1092.93 gram, dengan diketahui beban kering dan beban basah maka besar prosentase daya serap air yaitu $18.13 \%$.

Tabel 9 Hasil Pengujian Section Rate Batu Bata Normal

\begin{tabular}{|c|c|c|c|c|c|c|c|}
\hline \multirow{11}{*}{ 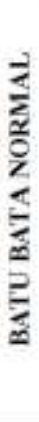 } & BENDA EN & PANUANG (CMD) & LEBAR (CM) & Tras (Cas) & BHBAN KERING (GRAM) & BEBAN BUSAH (GRAM) & DAYA SERAP AIR (GKANIDNIAIENIT) \\
\hline & 1 & 21,70 & 9,00 & 4,00 & 1177,10 & 1229,50 & 4,45 \\
\hline & 2 & 21,70 & 8,80 & 5,30 & 1047,30 & 1184,30 & 13,08 \\
\hline & 3 & 22.20 & 9,60 & 4,40 & 1094,70 & 1260,10 & 15,11 \\
\hline & 4 & 21,50 & 8,60 & 4,80 & 1091,10 & 1301,90 & 19,32 \\
\hline & 5 & 21,20 & 9,00 & 4,60 & 100250 & 1149,40 & 14,65 \\
\hline & 6 & 21,70 & 9,30 & 5,00 & 1205,60 & 1493,10 & 23,85 \\
\hline & 7 & 21,20 & 9,20 & 5.10 & 1241,60 & 1510,10 & 21,63 \\
\hline & 8 & 21,30 & 9,10 & 4,80 & 1191,00 & 1462,40 & 22,79 \\
\hline & 9 & 21,70 & 9,10 & 4,30 & 785,50 & 1007,60 & 28.27 \\
\hline & RATARATA & 21,58 & 9,08 & 4,70 & 1092,93 & 1288,71 & 18,13 \\
\hline
\end{tabular}

Hasil penimbangan batu bata dengan onggok $25 \%$ pada saat beban basah mempunyai nilai rata- rata 1478.83 gram, sedangkan beban kering yang terjadi adalah 1196.57 gram, dengan diketahui beban kering dan beban basah maka besar prosentase daya serap air yaitu $23.60 \%$. 
Tabel 10 Hasil Pengujian Section Rate Batu Bata dengan Onggok 25\%

\begin{tabular}{|c|c|c|c|c|c|c|c|}
\hline \multirow{10}{*}{ 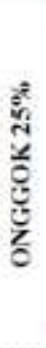 } & 1 & 21,00 & 9,20 & 4,50 & 1228,10 & 1540,60 & 25,45 \\
\hline & 2 & 21,50 & 9,20 & 4,50 & 1176,80 & 1478,70 & 25.65 \\
\hline & 3 & 21,50 & 9,50 & 4,80 & 1214,50 & 1463,90 & 20,54 \\
\hline & 4 & 21,00 & 9,50 & 4,70 & 1185,30 & 1489,60 & 25,67 \\
\hline & 5 & 21,00 & 9,50 & 4,50 & 1176,80 & 1434,40 & 21.89 \\
\hline & 6 & 21,00 & 9,00 & 5,00 & 1221,90 & 1484,50 & 21,49 \\
\hline & 7 & 22,00 & 9,00 & 4,80 & 1198,40 & 1486,00 & 24,00 \\
\hline & 8 & 21,00 & 8,90 & 4,50 & 1173,70 & 1440,40 & 22,72 \\
\hline & 9 & 21,00 & 9,00 & 5,00 & 1193,60 & 1691,40 & 24,95 \\
\hline & RATA-RATA & 21,22 & 9,20 & 4,70 & 1196,57 & 1478,83 & 23,60 \\
\hline
\end{tabular}

Sumber : Hasil analisis Peneliti, 2017

Data hasil penimbangan batu bata dengan onggok $50 \%$ pada saat beban basah mempunyai nilai rata- rata 1470.83 gram, sedangkan beban kering yang terjadi adalah 1140.39 gram, dengan diketahui beban kering dan beban basah maka besar prosentase daya serap air yaitu $28.97 \%$

Tabel 11 Hasil Pengujian Section Rate Batu Bata dengan Onggok 50\%

\begin{tabular}{|c|c|c|c|c|c|c|c|}
\hline \multirow{11}{*}{$\begin{array}{l}\frac{2}{0} \\
\frac{0}{0} \\
\frac{0}{0} \\
\frac{2}{0}\end{array}$} & BENDA EII & PANJANG (CM) & LEASR (CAM) & TEBAL (CAP) & BEBA N KERIVG (GRAM) & BEBAN BASAH (GRAM) & DAVA SERAP AIR (GRAMDDI3AIENT) \\
\hline & 1 & 22,50 & 920 & 4,50 & 1099,40 & 1420,00 & 29,16 \\
\hline & 2 & 22,00 & 9,80 & 4,30 & 1112,00 & 1420,40 & 27,73 \\
\hline & 3 & 22,00 & 9,50 & 4,50 & 1143,10 & 1485,00 & 29,91 \\
\hline & 4 & 22,00 & 920 & 5,00 & 1140,80 & 1471,60 & 29,00 \\
\hline & 5 & 22,30 & 9,80 & 4.00 & 1092,90 & 1406,70 & 28,71 \\
\hline & 6 & 22,50 & 9,50 & 5,50 & 1181,60 & 1524,50 & 29,02 \\
\hline & 7 & 23,00 & 9.00 & 5,00 & 1126,90 & 1449,70 & 28,64 \\
\hline & 8 & 23,00 & 920 & 5,00 & 1200,20 & 1560,70 & 30,04 \\
\hline & 9 & 22,50 & 9,50 & 5,50 & 1166,60 & 1498,90 & 28,48 \\
\hline & RATA-RATA & 22,42 & 9,41 & 4,81 & 1140,39 & 1470,83 & 28,97 \\
\hline
\end{tabular}

Sumber : Hasil Analisis Peneliti, 2017

Hasil penimbangan batu bata dengan onggok $100 \%$ pada saat beban basah mempunyai nilai rata- rata 1466.62 gram, sedangkan beban kering yang terjadi adalah 1109.56 gram, dengan diketahui beban kering dan beban basah maka besar prosentase daya serap air yaitu $32.21 \%$

Tabel 12 Hasil Pengujian Section Rate Batu Bata dengan Onggok $100 \%$

\begin{tabular}{|c|c|c|c|c|c|c|c|}
\hline \multirow{10}{*}{ 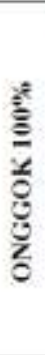 } & 1 & 23,00 & 9,50 & 4,50 & 1115,60 & 1457,30 & 30,63 \\
\hline & 2 & 23,00 & 9,20 & 5,00 & 1149,00 & 1490,90 & 29,76 \\
\hline & 3 & 22.50 & 9.50 & 4,50 & 1085,00 & 1451,60 & 33,79 \\
\hline & 4 & 2250 & 9,30 & 4,50 & 1095,30 & 1448,50 & 32,25 \\
\hline & 5 & 22,50 & 9,00 & 5,00 & 1155,70 & 1513,60 & 30,97 \\
\hline & 6 & 22,50 & 9,50 & 5.00 & 1090,10 & 1431,30 & 31,30 \\
\hline & 7 & 22,50 & 10,00 & 4,50 & 1130,00 & 1493,00 & 32,12 \\
\hline & 8 & 23,00 & 9,50 & 4,50 & 1096,50 & 1479,60 & 34,94 \\
\hline & 9 & 23,00 & 9.80 & 5.00 & 1068,80 & 1433,80 & 34,15 \\
\hline & RATARATA & 22,72 & 9,50 & 4,72 & 1109,56 & 1466,62 & 32,21 \\
\hline
\end{tabular}

Sumber : Hasil Analisis Peneliti, 2017

4. Uji kuat tekan

Proses uji tekan dilakukan menggunakan sampel batu bata berrongga yang akan diuji kuat tekan hingga material tersebut hancur serta dilakukan pencatatan beban maksimum yang terjadi, hasil uji kuat tekan batu bata normal dengan luas penampang rata-rata $25 \mathrm{~cm}^{2}$, dengan berat rata-rata benda uji $0.140 \mathrm{~kg}$, dan beban maksimum rata-rata $171 \mathrm{~kg}$ maka didapat kuat tekan yang terjadi 6.84 $\mathrm{kg} / \mathrm{cm}^{2}$. 
Tabel 13 Hasil Pengujian Kuat Tekan Batu Bata Normal

\begin{tabular}{|c|c|c|c|c|c|c|c|c|}
\hline \multirow{7}{*}{ 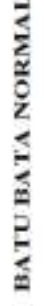 } & BENDA CII & PANJANG (CM) & LEAR (CM) & IEBAL (CA) & LEAS PENAMPAXG TEKUX (CML) & BERAI BENDA CJI (KG) & BEBAX MLKKSDLL (KG) & KTAI IEKAX (NGCAL2) \\
\hline & 1 & 9,00 & 5,00 & $\$, 00$ & 25,00 & 0,152 & 150,00 & 6,000 \\
\hline & 2 & 5,00 & 5,00 & 5,00 & 25,00 & 0,136 & 160,00 & 6,400 \\
\hline & 3 & 5,00 & 5,00 & $\$, 00$ & 25,00 & 0,170 & 170,00 & 6,800 \\
\hline & 4 & 5,00 & 5,00 & 5,00 & 25,00 & 0,136 & 180,00 & 7,200 \\
\hline & 5 & 5,00 & 5,00 & 5,00 & 25,00 & 0,108 & 195,00 & 7,800 \\
\hline & RATA-RATA & 5,00 & 5,00 & 5,00 & 25,00 & 0,140 & 171,00 & 6,840 \\
\hline
\end{tabular}

Sumber : Hasil Analisis Peneliti, 2017

Hasil uji kuat tekan batu bata dengan onggok $25 \%$ yang mempunyai luas penampang rata-rata $25 \mathrm{~cm}^{2}$, dengan berat rata-rata benda uji $0.156 \mathrm{~kg}$, dan beban maksimum rata-rata $185 \mathrm{~kg}$ maka didapat kuat tekan yang terjadi 7.408 $\mathrm{kg} / \mathrm{cm}^{2}$.

Tabel 14 : Hasil Pengujian Kuat Tekan Batu Bata dengan Onggok 25 \%

\begin{tabular}{|c|c|c|c|c|c|c|c|c|}
\hline \multirow{6}{*}{ 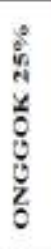 } & 1 & 5,00 & 5,00 & 5,00 & 25,00 & 0,161 & 196,00 & 7,840 \\
\hline & 2 & 5,00 & 5,00 & 5,00 & 25,00 & 0,157 & 198,00 & 7,920 \\
\hline & 3 & 5,00 & 5,00 & 5,00 & 25,00 & 0,139 & 172,00 & 6,850 \\
\hline & 4 & 5,00 & 5,00 & 5,00 & 25,00 & 0,164 & 162,00 & 6,480 \\
\hline & 5 & 5,00 & 5,00 & 5,00 & 25,00 & 0,160 & 198,00 & 7920 \\
\hline & R.ATA-RATA & 5,00 & 5,00 & 5,00 & 25,00 & 0,156 & 185,20 & 7,408 \\
\hline
\end{tabular}

Sumber : Hasil Analisis Peneliti, 2017

Hasil uji kuat tekan batu bata dengan onggok $50 \%$ yang mempunyai luas penampang rata-rata $25 \mathrm{~cm}^{2}$, dengan berat rata-rata benda uji $0.155 \mathrm{~kg}$, dan beban maksimum rata-rata $136.86 \mathrm{~kg}$ maka didapat kuat tekan yang terjadi $5.474 \mathrm{~kg} / \mathrm{cm}^{2}$.

Tabel 15 Hasil Pengujian Kuat Tekan Batu Bata dengan Onggok 50 \%

\begin{tabular}{|c|c|c|c|c|c|c|c|c|}
\hline \multirow{9}{*}{ 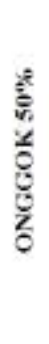 } & BENDACI & PANJAXGG & LEBAR (CM) & IEBAL (CAD) & ULAS PENAMPAXG TEKAN (CMD) & BERAT BEXDA LJI (KG) & BEALN MLAKSTLAL (KC) & KCAT TFGAN (KGCAR) \\
\hline & 1 & 5,00 & 5,00 & 5,00 & 25,00 & 0,164 & 182,00 & 7,280 \\
\hline & 2 & 5,00 & 5,00 & 3,00 & 25,00 & 0,162 & 110,00 & 4,400 \\
\hline & 3 & 5,000 & 5,00 & 5,00 & 25,00 & 0,140 & 170,00 & 6.800 \\
\hline & 4 & 5,00 & 5,00 & 5,00 & 25,00 & 0,156 & 118,00 & 4,720 \\
\hline & 5 & 5,00 & 5,00 & 5,00 & 25,00 & 0,150 & 148,00 & 5920 \\
\hline & 6 & 5,00 & $\$, 00$ & 5,00 & 25,00 & 0,145 & 112,00 & 4,450 \\
\hline & 7 & 5,00 & 5,00 & 5,00 & 25,00 & 0,165 & 118,00 & 4,720 \\
\hline & EATARATA & 5,00 & 5,00 & 5,00 & 25,00 & 0,155 & 136,86 & 5,474 \\
\hline
\end{tabular}

Sumber : Hasil Analisis Peneliti, 2017

Hasil uji kuat tekan batu bata dengan onggok $100 \%$ yang mempunyai luas penampang rata-rata $25 \mathrm{~cm}^{2}$, dengan berat rata-rata benda uji $0.136 \mathrm{~kg}$, dan beban maksimum rata-rata $94.86 \mathrm{~kg}$ maka didapat kuat tekan yang terjadi $3.794 \mathrm{~kg} / \mathrm{cm}^{2}$

Tabel 16 : Hasil Pengujian Kuat Tekan Batu Bata dengan Onggok $100 \%$

\begin{tabular}{|c|c|c|c|c|c|c|c|c|}
\hline \multirow{8}{*}{ 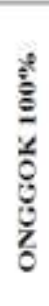 } & 1 & 5,00 & 5,00 & 5,00 & 25,00 & 0,126 & 148,00 & $\$, 520$ \\
\hline & 2 & 5,00 & 9,00 & 5,00 & 25,00 & 0,127 & 70,00 & 2800 \\
\hline & 3 & 5,00 & 5,00 & 5,00 & 23,00 & 0,138 & 78,00 & 3,120 \\
\hline & 4 & 5,00 & 5,00 & 5,00 & 25,00 & 0,138 & 50,00 & 2000 \\
\hline & 5 & 5,00 & 5.00 & 5,00 & 25,00 & 0.159 & 170,00 & 6.800 \\
\hline & 6. & 5,00 & 5,00 & 5,00 & 25,00 & 0,118 & 76,00 & 3,040 \\
\hline & 7 & 5,00 & 5,00 & 5,00 & 25,00 & 0,142 & 72,00 & 2,850 \\
\hline & RATA-RATA & 5,00 & 5,00 & 5,00 & 25,00 & 0,136 & 94,86 & 3,794 \\
\hline
\end{tabular}


Gabungan grafik analisa dan uji kuat tekan batu bata dari sampel 1 sampai sampel 5 didapat beban terkecil $50 \mathrm{~kg}$ sampai beban terbesar $198 \mathrm{~kg}$ dengan kuat tekan terkecil $2 \mathrm{~kg} / \mathrm{cm}^{2}$ sampai kuat tekan terbesar $7,9 \mathrm{~kg} / \mathrm{cm}^{2}$ sehingga didapat rata - rata beban adalah $146,98 \mathrm{~kg}$ dan rata - rata kuat tekan adalah $5,85 \mathrm{~kg} / \mathrm{cm}^{2}$. Pada sampel bata normal dengan campuran sekam padi terlihat bahwa kuat tekan terjadi terus meningkat dimana kuat tekan terkecil yaitu 6 $\mathrm{kg} / \mathrm{cm}^{2}$ sampai dengan $7,8 \mathrm{~kg} / \mathrm{cm}^{2}$, Sedangkan batu bata dengan campuran onggok $25 \%$ mempunyaik kuat tekan rata - rata hampir sama dengan batu bata normal dengan nilai tekan $7,4 \mathrm{~kg} / \mathrm{cm}^{2}$. Sedangkan untuk sampel dengan campuran onggok $50 \%$ dan $100 \%$ mempunyai nilai rata rata $5,4 \mathrm{~kg} / \mathrm{cm}^{2}$ dan 3,79 $\mathrm{kg} / \mathrm{cm}^{2}$, sehingga dibandingkan dengan batu bata normal kuat tekan jauh lebih kecil. Oleh karena itu dari nilai kuat tekan batu bata normal masih lebih baik katrena rata - rata nilainya adalah $6,84 \mathrm{~kg} / \mathrm{cm}^{2}$ dibanding dengan batu bata dengan campuran onggok yang relatif lebih kecil yaitu $5 \mathrm{~kg} / \mathrm{cm}^{2}$ dan mempunyai penyerapan kadar air yang tinggi. Untuk perbandingan grafik antara beban dan kuat tekan yang dihasilkan dapat dilihat pada Gambar 1.

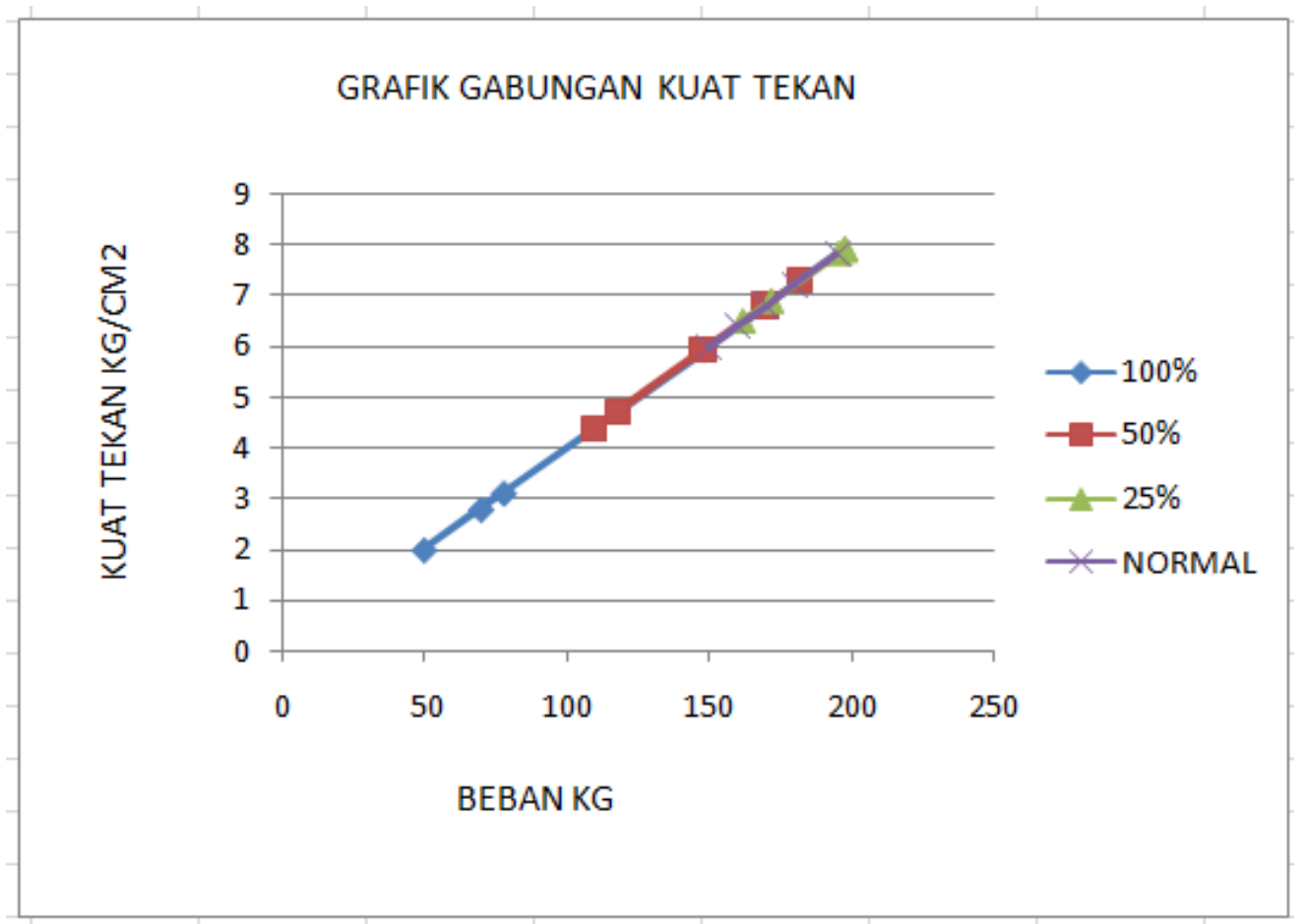

G

Sumber : Hasil Analisis Peneliti, 2017

Gambar 1. Gabungan Uji Tekan Batu Bata

\section{KESIMPULAN DAN SARAN}

\section{Kesimpulan}

Dari hasil analisis kuat tekan batu bata dengan onggok sebagai bahan pengganti sekam padi dapat diambil beberapa kesimpulan sebagai berikut : 
1. Kuat tekan yang dihasilkan batu bata dengan sekam padi mempunyai kuat tekan yang lebih tinggi dengan kadar penyerapan air dalam batas yang diijinkan yaitu sebesar $18 \%$ dari daya serap ijin $20 \%$ dengan kuat rata - rata $6,84 \mathrm{~kg} / \mathrm{cm}^{2}$ sehingga batu bata dengan campuran sekam padi lebih baik dari batu bata dengan campuran limbah onggok yang mempunyai daya serap air rata - rata $25 \%$ melebihi daya serap yang diijinkan, serta mempunyai kuat tekan relatif kecil dengan rata - rata $5 \mathrm{~kg} / \mathrm{cm}^{2}$ Oleh karena itu campuran dengan limbah onggok hanya diperkenankan untuk bangunan yang bersifat non struktur.

2. Penyerapan air yang tinggi disebabkan karena sifat dari limbah onggok yang bersifat panas karena limbah onggok mempunyai serat serabut yang kasar, dibandingkan dengan serat yang ada pada campuran batu bata dengan sekam padi yang relatif lebih halus.

\section{Saran}

Saran yang dapat diberikan sebagai masukan dalam penelitian yang relevan dengan penelitian ini adalah :

1. Walaupun dengan pencampuran bata dengan onggok $25 \%$ menghasilkan nilai kuat tekan yang tinggi, perlu dipertimbangkan juga penyerapan kadar air yang tinggi dapat mengakibatkan dinding berair, maka disaat penggunaan batu bata ini penyiraman atau pembasahan batu bata harus diperhatikan.

2. Perlu adanya penelitian lanjut tidak hanya sebatas mencari nilai kuat tekan yang tinggi tetapi perlu adanya penelitian homogenitas pencampuran material semen maupun pasir yang dicampur dengan limbah onggok bertujuan untuk mencari kuat tekan yang diharapkan dan daya serap air pada batas ijin.

\section{DAFTAR PUSTAKA}

Badan Standarisasi Nasional SK- SNI S-04-1989

Indra, A., 2013, Pengaruh Temperatur Pembakaran pada Komposit Lempung/Silica RHA Terhadap Sifat Fisis (Aplikasi pada Batu Bata Merah), Jurnal Teknik Mesin, Institusi Teknologi Padang.

Lakum, K., 2009, Batas Izin Air Untuk Campuran Beton, Jurnal MIPA, USU.

Lempang, M., 2012, Efektivitas Nila Aren Sebagai Bahan Pengembang Adonan Roti, Jurnal Penelitian Kehutanan Wallacae, Balai Penelitian Kehutanan Makasar.

Mardiyati, 2010, Optimasi Suhu Pembakaran Batu Bata Merah dengan Penambahan Limbah Batu Bara untuk Meningkatkan Kualitas Batu Bata Merah, Prosiding Pertemuan IImiah XXIV HFI Jateng dan DIY.

Marwah, Y., 2014, Kuat Tekan Batu Bata Berbahan Limbah Pabrik Gula, Seminar Nasional dan Call for Papers, UNIBA.

Pamungkasih, E., 2013, Briket dari Ampas Aren, Jurnal Universitas Gajah Mada.

Sudarsana, K., 2011, Karakteristik Batu Bata Tanpa Pembakaran Terbuat dari Abu Sekam Padi dan Serbuk Batu Tabas, Jurnal IImiah Teknik Sipil, Universitas Udayana. Denpasar.

Sukirno, 2014, Sifat - Sifat Tanah Lempung, Jurnal Teknik Unila

Suwardono, 2015, Pemanfaatan Lempung Sebagai Bahan Baku Gerabah, Seminar Nasional Sains dan Teknologi Terapan III 2015, Institut Teknologi Adhi Tama Surabaya 
